\title{
IPTEKS PENGHITUNGAN NILAI MARKET VALUE ADDED ATAS
}

KEPUTUSAN INVESTASI

\author{
Mario Yohanis Thomas \\ Program Studi Profesi Akuntan, Fakultas Ekonomi dan Bisnis, Universitas Sam Ratulangi, Jl. Kampus Bahu, \\ Manado, 95115, Indonesia. \\ E-mail: mythomas8796@gmail.com
}

\begin{abstract}
Development in technology has triggered the aggresivity of stock practitioners to make transactions in the stock market, so the portofolio analyzing skill is in high demand. This article practically explains about the implementation of Market Value Added (MVA) to support decision-making for investors. The formula is applied to 10 sample of public corporations listed in the Indonesia Stock Exchange. The results show that 6 firms have a positive MVA value, therefore they are fundamentally good for investing. On the other hand, the remaining 4 are showing MVA values below 0 because they are not able to gain company value above their total investment.
\end{abstract}

Keywords: MVA; investment; fundamental; performance; shares

\section{PENDAHULUAN}

Perkembangan di bidang teknologi memberi kemudahan kepada para investor dalam mengevaluasi portofolio emiten-emiten saham, dengan fasilitas seperti transaksi real-time dan layanan aplikasi charting. Berbagai fitur ditawarkan dalam kecanggihan teknologi guna mewujudkan investasi yang efektif dan efisien. Untuk itu, pelaku-pelaku pasar saham pada masa kini dituntut untuk memiliki kecerdasan investasi yang dapat mengimbangi kelajuan teknologi di bidang keuangan, khususnya investasi pada pasar modal.

Salah satu indikator fundamental kinerja keuangan dalam analisis laporan keuangan adalah profitabilitas yang dapat diproksikan dengan Market Value Added (MVA). Indikator ini menunjukkan selisih nilai pasar terhadap nilai investasi, sehingga mencerminkan seberapa besar peningkatan nilai sebuah perusahaan melalui sudut pandang pasar. Urgensi dari kajian ini adalah untuk memberikan kepada masyarakat pemahaman yang baik dalam melakukan transaksi di pasar modal guna mengimbangi perkembangan yang pesat dalam dunia saham modern. Selain itu, indikator MVA merupakan nilai yang diperoleh dari perhitungan yang relatif mudah untuk dilakukan oleh seluruh kalangan masyarakat.

\section{TINJAUAN PUSTAKA}

Analisis fundamental

Jones (2013:303) menyatakan bahwa analisis fundamental adalah studi terhadap nilai saham menggunakan basis seperti pendapatan, penjualan, risiko, dan sebagainya. Analisis fundamental digunakan oleh investor untuk menentukan saham yang harga pasarnya lebih rendah dari nilai intrinsiknya (undervalued) sehingga layak dibeli serta saham yang harga pasarnya lebih tinggi dari nilai intrinsiknya (overvalued) sehingga menguntungkan untuk dijual. Memilih investasi memerlukan pertimbangan dengan melakukan analisis fundamnental dan analisis teknikal. Proses analisis penilaian saham terdiri dari tiga tahapan, yakni analisis ekonomi, analisis industri, dan analisis perusahaan untuk memperhitungkan nilai dari saham perusahaan (Jones, 2013:348).

Menurut Sutrisno (2012:309), analisis fundamental merupakan pendekatan analisis harga saham yang menitikberatkan pada kinerja perusahaan yang mengeluarkan saham dan 
analisis ekonomi yang akan mempengaruhi masa depan perusahaan. Menurut Tandelilin (2010:338), analisis fundamental merupakan analisis terhadap faktor-faktor makro ekonomi yang mempengaruhi kinerja seluruh perusahaan-perusahaan, kemudian dilanjutkan dengan dengan analisis industri, dan pada akhirnya dilakukan analisis terhadap perusahaan yang mengeluarkan sekuritas bersangkutan untuk menilai apakah sekuritas yang dikeluarkannya menguntungkan atau merugikan bagi investor.

\section{Pasar modal dan kinerja keuangan}

Husnan (2015:3) mendefinisikan bahwa secara formal pasar modal adalah pasar untuk instrumen keuangan (atau sekuritas) jangka panjang yang bisa diperjualbelikan, baik dalam bentuk utang ataupun modal sendiri, baik yang diterbitkan pemerintah, public authorities, maupun perusahaan swasta. Rudianto (2013:189) mendefinisikan bahwa kinerja keuangan adalah hasil atau prestasi yang telah dicapai oleh manajemen perusahaan dalam menjalankan fungsinya untuk mengelola aset perusahaan secara efektif selama periode tertentu sehingga kinerja keuangan sangat dibutuhkan oleh perusahaan untuk mengetahui dan mengevaluasi sampai dimana tingkat keberhasilan perusahaan berdasarkan aktivitas keuangan yang telah dilaksanakan. Fahmi (2017:2) mendefinisikan bahwa kinerja keuangan adalah suatu analisis yang dilakukan untuk melihat sejauh mana suatu perusahaan telah melaksanakan dengan menggunakan aturan-aturan pelaksanaan keuangan dengan baik dan benar, misalnya menyajikan laporan keuangan yang telah memenuhi standar dan ketentuan dalam Standar Akuntansi Keuangan (SAK) atau Generally Accepted Accounting Principles (GAAP). Prastowo (2011:92) mendefinisikan bahwa unsur dari kinerja keuangan perusahaan adalah unsur yang berkaitan secara langsung dengan pengukuran kinerja perusahaan yang disajikan pada laporan laba rugi, penghasilan bersih seringkali digunakan sebagai ukuran kinerja atau sebagian dasar bagi ukuran lainnya.

\section{Manajemen keuangan}

Van Horne dan Wachowicz (2009:2) menjelaskan bahwa manajemen keuangan berhubungan dengan perolehan, pendanaan, dan pengelolaan aset dengan beberapa tujuan secara keseluruhan sehingga fungsi keputusan dari manajemen keuangan dapat dibagi menjadi tiga area utama, yaitu keputusan investasi, pendanaan, dan pengelolaan aset. Menurut Harjito dan Martono (2007:4), manajemen keuangan adalah segala aktivitas perusahaan yang berhubungan dengan bagaimana memperoleh dana, menggunakan dana dan mengelola aset sesuai tujuan perusahaan secara menyeluruh.

\section{Market Value Added (MVA)}

Brigham dan Houston (2015:78), Brigham dan Ehrhardt (2017:81), dan Melicher dan Norton (2017:403) menjelaskan bahwa Market Value Added (MVA) adalah perbedaan antara nilai pasar ekuitas suatu perusahaan dengan nilai buku seperti yang disajikan dalam neraca, nilai pasar dihitung dengan mengalikan harga saham dengan jumlah saham yang beredar. Menurut Keown (2010:35), MVA merupakan alat untuk mengukur berapa banyak kekayaan suatu perusahaan yang telah diciptakan untuk saat tertentu. Sartono (2001:105) mengemukakan cara menginterpretasi nilai MVA yaitu:

1. MVA positif $(>0)$ berarti pihak manajemen telah mampu meningkatkan kekayaan perusahaan dan kekayaan para pemegang saham pun menjadi bertambah.

2. MVA negatif $(<0)$ berarti pihak manajemen telah menurunkan kekayaan perusahaan dan kekayaan para pemegang saham pun menjadi berkurang. 


\section{METODE DAN TEKNIK PENERAPAN IPTEKS}

\subsection{Metode penerapan ipteks}

Penerapan ipteks dilakukan dengan menghitung nilai MVA dari perusahaanperusahaan objek. Data diperoleh dari ringkasan laporan kinerja perusahaan per Desember 2018 yang ditampilkan dalam situs resmi BEI (www.idx.co.id). Objek yang diambil adalah 10 perusahaan publik yang terdaftar pada Bursa Efek Indonesia (BEI).

\subsection{Teknik penerapan ipteks}

Keown (2010:35), dan Brealey et al. (2020:748) menghitung MVA sebagai selisih antara nilai perusahaan dengan modal yang diinvestasikan, dimana nilai perusahaan diperoleh dari jumlah saham beredar dikalikan harga pasar saham sedangkan modal yang diinvestasikan diperoleh dari total utang ditambah ekuitas dikurangi utang jangka pendek.

\section{PEMBAHASAN}

\subsection{Gambaran objek penerapan ipteks}

Objek penerapan ipteks adalah perusahaan-perusahaan yang terdaftar dalam Bursa Efek Indonesia (BEI). BEI sendiri adalah pihak yang menyelenggarakan dan menyediakan sistem juga sarana untuk mempertemukan penawaran jual dan beli efek pihak-pihak lain dengan tujuan memperdagangkan efek di antara mereka.

\subsection{Pembahasan}

Nilai perusahaan objek diperoleh dengan mengalikan jumlah saham beredar dengan harga saham. Tabel 1 menyajikan rincian perhitungan nilai perusahaan objek.

Tabel 1. Nilai perusahaan tahun 2018

\begin{tabular}{lcrrr}
\hline \multicolumn{1}{c}{$\begin{array}{c}\text { Nama } \\
\text { perusahaan }\end{array}$} & $\begin{array}{c}\text { Kode } \\
\text { emiten }\end{array}$ & $\begin{array}{c}\text { Jumlah } \\
\text { saham } \\
\text { beredar }\end{array}$ & $\begin{array}{c}\text { Harga } \\
\text { pasar } \\
\text { saham }\end{array}$ & $\begin{array}{c}\text { Nilai } \\
\text { perusahaan }\end{array}$ \\
\hline Ace Hardware Indonesia Tbk. & ACES & 17,150 & 1,490 & $25,553,500$ \\
Adira Dinamika Multi Finance Tbk. & ADMF & 1,000 & 9,100 & $9,100,000$ \\
Agung Podomoro Land Tbk. & APLN & 19,365 & 152 & $2,943,480$ \\
Ciputra Development Tbk. & CTRA & 18,560 & 1,010 & $18,745,600$ \\
Gudang Garam Tbk. & GGRM & 1,924 & 83,625 & $160,894,500$ \\
H. M. Sampoerna Tbk. & HMSP & 116,318 & 3,710 & $431,539,780$ \\
Indofood CBP Sukses Makmur Tbk. & ICBP & 11,662 & 10,450 & $121,867,900$ \\
Mayora Indah Tbk. & MYOR & 22,359 & 2,620 & $58,580,580$ \\
Sumber Alfaria Trijaya Tbk. & AMRT & 41,525 & 935 & $38,825,875$ \\
Waskita Karya (Persero) Tbk. & WSKT & 13,574 & 1,680 & $22,804,320$ \\
\hline Disajikan dalam jutaan Rupiah, kecuali jumlah saham beredar & & &
\end{tabular}

Tabel 2 menyajikan perhitungan modal yang diinvestasikan oleh masing-masing perusahaan pada periode yang berakhir pada tahun 2018 .

Tabel 2. Perhitungan Modal yang Diinvestasikan Tahun 2018

\begin{tabular}{lcrrrr}
\multicolumn{1}{c}{$\begin{array}{c}\text { Nama } \\
\text { perusahaan }\end{array}$} & Kode emiten & \multicolumn{1}{c}{$\begin{array}{c}\text { Total } \\
\text { utang }\end{array}$} & $\begin{array}{c}\text { Total } \\
\text { ekuitas }\end{array}$ & $\begin{array}{r}\text { Utang } \\
\text { jangka } \\
\text { pendek }\end{array}$ & $\begin{array}{c}\text { Modal } \\
\text { yang } \\
\text { diinvestasikan }\end{array}$ \\
\hline Ace Hardware Indonesia Tbk. & ACES & $1,048,666$ & $3,825,100$ & 548,381 & $4,325,385$ \\
Adira Dinamika Multi Finance Tbk. & ADMF & $24,290,399$ & $6,450,505$ & 90,877 & $30,650,027$ \\
Agung Podomoro Land Tbk. & APLN & $17,234,426$ & $11,839,369$ & 603,806 & $28,469,989$ \\
Ciputra Development Tbk. & CTRA & $17,633,328$ & $15,976,682$ & 805,002 & $32,805,008$ \\
Gudang Garam Tbk. & GGRM & $23,823,661$ & $42,927,699$ & $21,753,835$ & $44,997,525$ \\
H. M. Sampoerna Tbk. & HMSP & $17,706,294$ & $31,407,982$ & $15,236,730$ & $33,877,546$ \\
Indofood CBP Sukses Makmur Tbk. & ICBP & $11,896,918$ & $21,923,346$ & $7,397,157$ & $26,423,107$ \\
Mayora Indah Tbk. & MYOR & $10,156,612$ & $7,861,408$ & $4,687,655$ & $13,330,365$ \\
Sumber Alfaria Trijaya Tbk. & AMRT & $15,837,788$ & $5,512,166$ & $11,181,219$ & $10,168,735$ \\
Waskita Karya (Persero) Tbk. & WSKT & $102,231,720$ & $27,013,040$ & $17,108,371$ & $112,136,389$ \\
\hline Disajkan dam
\end{tabular}

Disajikan dalam jutaan Rupiah 
Tabel 3 menyajikan perhitungan MVA yang diperoleh dari nilai perusahaan dikurangi modal yang diinvestasikan. Berdasarkan hasil perhitungan, diketahui bahwa perusahaan dengan kode emiten ACES, GGRM, HMSP, ICBP, MYOR, dan AMRT memiliki nilai MVA positif. Sesuai konsep dari Sartono (2001:105), hasil ini mengindikasikan manajemen perusahaan menunjukkan performa yang baik dalam meningkatkan kekayaan perusahaan dan kekayaan investor. Keenam perusahaan ini menunjukkan nilai nilai kapitalisasi pasar atas saham yang melebihi total investasi atas perusahaan-perusahaan tersebut, sehingga saham dapat dijual dengan harga premium. Diantara perusahaan-perusahaan tersebut, HMSP adalah perusahaan yang memiliki nilai MVA tertinggi. Di samping itu, beberapa perusahaan menunjukkan nilai MVA negatif, yakni perusahaan dengan kode emiten ADMF, APLN, CTRA, dan WSKT. Hal ini mengindikasikan bahwa pihak manajemen belum mencapai kekayaan perusahaan optimal sehingga kekayaan para pemegang saham pun menjadi tidak optimal. Keempat perusahaan dengan nilai MVA negatif ini tidak memberikan nilai tambah melalui pertumbuhan nilai kapitalisasi pasar atas total modal yang diinvestasikan. Diantara perusahaan-perusahaan ini, WSKT memiliki nilai paling rendah.

Tabel 3. Perhitungan MVA tahun 2018

\begin{tabular}{clrrrr}
\hline No. & \multicolumn{1}{c}{$\begin{array}{c}\text { Nama } \\
\text { perusahaan }\end{array}$} & $\begin{array}{c}\text { Kode } \\
\text { emiten }\end{array}$ & $\begin{array}{c}\text { Nilai } \\
\text { perusahaan }\end{array}$ & $\begin{array}{c}\text { Modal } \\
\text { yang } \\
\text { diinvestasikan }\end{array}$ & MVA \\
\hline 1 & Ace Hardware Indonesia Tbk. & ACES & $25,553,500$ & $4,325,385$ & $21,228,115$ \\
2 & Adira Dinamika Multi Finance Tbk. & ADMF & $9,100,000$ & $30,650,027$ & $-21,550,027$ \\
3 & Agung Podomoro Land Tbk. & APLN & $2,943,480$ & $28,469,989$ & $-25,526,509$ \\
4 & Ciputra Development Tbk. & CTRA & $18,745,600$ & $32,805,008$ & $-14,059,408$ \\
5 & Gudang Garam Tbk. & GGRM & $160,894,500$ & $44,997,525$ & $115,896,975$ \\
6 & H. M. Sampoerna Tbk. & HMSP & $431,539,780$ & $33,877,546$ & $397,662,234$ \\
7 & Indofood CBP Sukses Makmur Tbk. & ICBP & $121,867,900$ & $26,423,107$ & $95,444,793$ \\
8 & Mayora Indah Tbk. & MYOR & $58,580,580$ & $13,330,365$ & $45,250,215$ \\
9 & Sumber Alfaria Trijaya Tbk. & AMRT & $38,825,875$ & $10,168,735$ & $28,657,140$ \\
10 & Waskita Karya (Persero) Tbk. & WSKT & $22,804,320$ & $112,136,389$ & $-89,332,069$ \\
\hline
\end{tabular}

Disajikan dalam jutaan Rupiah

\section{KESIMPULAN DAN SARAN \\ 5.1. Kesimpulan}

Pada tahun 2018, ACES, GGRM, HMSP, ICBP, MYOR, dan AMRT mampu menciptakan nilai tambah atas saham yang diedarkan di pasar modal yang ditunjukkan dengan nilai MVA positif. Hal ini menjadikan perusahaan-perusahaan tersebut sebagai pilihan investasi yang prospektif sedangkan ADMF, APLN, CTRA, dan WSKT, memiliki nilai MVA yang negatif. Hal ini mengimplikasikan total investasi atas perusahaanperusahaan tersebut tidak menciptakan nilai pasar saham yang lebih tinggi dari total investasi sehingga memerlukan evaluasi lebih lanjut jika hendak melakukan investasi.

\subsection{Saran}

Penggunaan MVA sebagai alat bantu dalam melakukan analisis portofolio merupakan cara yang relatif mudah untuk dipraktekkan, terutama kepada investor-investor pemula. Investor dapat menginterpretasi nilai MVA positif sebagai informasi atas bertambahnya kekayaan perusahaan yang disebabkan oleh harga pasar yang lebih besar dari nilai buku. 


\section{DAFTAR PUSTAKA}

Brealey, R. A., Myers, S. C., \& Allen, F. (2020). Principles of Corporate Finance, $13^{\text {th }}$ Edition. United States McGraw-Hill Education.

Brigham, E. F., \& Ehrhardt, M. C. (2017). Financial Management: Theory \& Practice, $15^{\text {th }}$ Edition. United States: Cengage Learning.

Brigham, E. F., \& Houston, J. F. (2015). Fundamentals of Financial Management, $8^{\text {th }}$ Edition. United States: Cengage Learning.

Fahmi, I. (2017). Analisis Kinerja Keuangan. Bandung: Alfabeta.

Harjito, D. A., \& Martono, S. U. (2007). Manajemen keuangan. Yogyakarta: Ekonisia.

Husnan, S. (2015). Dasar-dasar teori portofolio dan analisis sekuritas Edisi 5. UPPN STIM YKPN. Yogyakarta.

Jones, C. P. (2013). Investment: Principles and Concepts, $12^{\text {th }}$ Edition. Singapore: John Wiley and Sons Pte. Ltd.

Keown, A. J. (2010). Financial Management: Principles and Applications. $10^{\text {th }}$ Edition. United States: Prentice Hall.

Melicher, R. W., \& Norton, E. A. (2017). Introduction to Finance Markets, Investments, and Financial Management, $16^{\text {th }}$ Edition. United States: John Wiley \& Sons, Inc.

Prastowo, D. (2011). Analisis Laporan Keuangan, Edisi 3. Jakarta: YKPN.

Rudianto, (2013). Akuntansi Manajemen Informasi untuk Pengambilan Keputusan Strategis. Jakarta: Penerbit Erlangga.

Sartono, A. (2001). Manajemen Keuangan Teori dan Aplikasi. Yogyakarta: BPFE.

Sutrisno. (2012). Manajemen Keuangan Teori, Konsep dan Aplikasi. Ekonisisa. Yogyakarta.

Tandelilin, E. (2010). Portofolio dan Investasi Teori dan Aplikasi. Edisi Pertama. Kanisius. Yogyakarta.

Van Horne, J. C., \& Wachowicz Jr., J. M., (2009). Fundamentals of Financial Management $13^{\text {th }}$ Edition. United Kingdom: Pearson Education Limited. 